International Journal of Agriculture, Environment and Bioresearch

Vol. 4, No. 05; 2019

ISSN: $2456-8643$

\title{
FACTORS AFFECTING THE DEVELOPMENT OF THE AGROPOLITAN AREA IN LEUWILIANG SUB DISTRICT, BOGOR REGENCY, WEST JAVA PROVINCE, INDONESIA
}

\author{
Reynaldi Elmir Arisurya ${ }^{1}$ and Raditia Eka Kurniawan ${ }^{2}$ \\ ${ }^{1,2}$ Department of Regional and Urban Planning, Faculty of Engineering, Diponegoro University, Semarang, Central \\ Java, Indonesia \\ http://doi.org/10.35410/IJAEB.2019.4430
}

\begin{abstract}
Agropolitan is one of an alternative to deal with development inequality in Indonesia which has a lot of potential natural resources in agriculture. Leuwiliang Sub District was determined by the government in 2004 as part of the agropolitan area in Bogor Regency. Unfortunately, the development of the Leuwiliang Agropolitan Area has not yet reached its goal. This is indicated by the low level of farmers income and environmental issues. This research aims to determine the factors that influence the development of the Leuwiliang Agropolitan Area. This type of research is a quantitative approach. This research has three main categories of variables, namely ecology, economy and social culture. This research uses primary data by using questionnaires to the fifty-eight (58) registered farmer groups as respondents (purposive sampling) and were analyzed by using confirmatory factor analysis in each category. The results show the use of organic pesticides (ecological category), farmers profit level (economic category) and support from farmers family members (social culture category) in the Leuwiliang Agropolitan Area are the most influential factor from each category towards the development of Leuwiliang Agropolitan Area. Based on the results of the analysis, some recommendations are needed for the development of the Leuwiliang Agropolitan Area namely strengthening the capacity of farmers to produce natural pesticides; strengthening the role of women and young farmers in agribusiness; and Increasing the efficiency of a sustainable agribusiness system to maximize farmers profit.
\end{abstract}

Keywords: Factor Analysis, Agropolitan, Regional Development.

\section{INTRODUCTION}

Agropolitan is one of an alternative to deal with development inequality in Indonesia which has a lot of potential natural resources in agriculture. Leuwiliang Sub District was determined by the government in 2004 as part of the agropolitan area in Bogor Regency. Unfortunately, the development of the Leuwiliang Agropolitan Area has not yet reached its goal. This is indicated by the low level of farmers income and environmental issues. This research aims to determine the factors that influence the development of the Leuwiliang Agropolitan Area. This type of research is a quantitative approach. This research has three main categories of variables, namely ecology, economy and social culture. This research uses primary data by using questionnaires to the fifty-eight (58) registered farmer groups as respondents (purposive sampling) and were analyzed by using confirmatory factor analysis in Agropolitan is one alternative to deal with 
development inequality in Indonesia that has a lot of potential of agricultural natural resources (Oktavia \& Saharuddin, 2013). The agropolitan approach provides an understanding that development in rural areas (rural development) can be done in parallel with urban areas (urban development). The concept of agropolitan was first introduced by Friedmann and Douglas (1975), as development activity in rural areas with a population of around 50,000-150,000 inhabitants where most of the people work in the agricultural sector and indicated the existence of regional disparities. The agropolitan area has several regional characteristics as revealed by Friedmann such as (i) relatively small area, (ii) the planning and decision-making process is autonomous and independent based on local community participation, (iii) diversification of rural labor in the agricultural sector and non-agriculture, emphasizing the growth of small industries (iv) the existence of functional relations between rural and urban industries and linkages with local economic resources, and (v) the utilization and improvement of the capacity of local resources and technology and (vi) the population in the city center ranges from 10,000 25,000 depends on the density (Lo \& Salih, 1978).

According to Nainggolan \& Aritonang (2012), although the development of rural agropolitan areas prioritizes the use of renewable resources, a number of other resources such as land, forests, water as basic production facilities in agribusiness have limited carrying capacity so that if not managed properly can hamper the development of agropolitan areas in the future. Lebacq et al (2013) divide the environmental dimensions into ten indicators that focus on the physical aspects of the environment and human activities that can impact on environmental conditions namely nutrition, pesticides, non-renewable resources (energy and water), land management, greenhouse gas emissions (GHG) and acidification substances, biodiversity, and physical, chemical and biological soil quality. Economic indicators can be seen from the aspect of production inputs. Besides, it can be seen from the aspects of financing (credit) as well as income from farming and household income of farmers (additional income outside the agricultural business). Subsidies are also included in aspects that affect economic sustainability, especially for agricultural businesses that are highly dependent on government subsidies (Bossel, 1999). Van Cauwenbergh et al (2007) considers the quality of life as a social indicator but is divided into physical well-being (labor conditions and health) and psychological well-being (education, gender equality, access to infrastructure and services, and farmer independence).

Leuwiliang Subdistrict is one of the Subdistricts determined by the government in 2004 as one of the sub-districts in the agropolitan area in Bogor Regency which is included in Zone I or the main zone of the agropolitan program. Leuwiliang Sub District become the main target for the implementation of the agropolitan program as well as being the center of agropolitan activity. The Leuwiliang Agropolitan Area has nine villages which are included in the Agropolitan area. Most of the Leuwiliang Subdistrict are rural areas which have large natural resources, especially in the agricultural sector.

Generally, the development of the Leuwiliang Agropolitan Area has not yet reached its goal. This is indicated by the low level of farmer income due to the lack of added value generated from the farming including investment (farmers, private sector, and BUMN) which is still low and natural resource management is not optimal (BP4K Bogor Regency, 2012). Besides, the low level of adoption of agricultural products processing technology in main commodities is also one of the obstacles in the development of the agropolitan area (Ismilaili et al., 2015). The proper development of the agropolitan area will provide great benefits for regional development. 
Based on Fatkhiati et al (2015) the agropolitan concept aims to improve the rural economy through the development of infrastructure and agribusiness activities in rural areas. The sustainable agropolitan area management model is a very appropriate concept to improve the economy of rural areas without causing environmental damage (Fatkhiati et al., 2015). Considering various conditions above it is very important to determine the factors that influence the development of the Leuwiliang Agropolitan Area.

\section{MATERIALS AND METHODS}

This research was conducted in the Agropolitan Area, Lewiliang Sub District, Bogor Regency. This location was chosen purposively because it is one of the sub-districts which in 2004 was designated by the government as part of the agropolitan area in Bogor Regency. This type of research is the quantitative approach. This research uses primary data by using questionnaires to the fifty-eight (58) registered farmer groups as respondents (purposive sampling). The variables that are used in this research divided into 3 main categories, namely ecology, economy and social culture. The results of the questionnaire were analyzed by using confirmatory factor analysis in each category. The analysis will reduce the number of variables based on their validity and reliability so that factors affecting the development of the Leuwiliang Agropolitan Area will be identified. Data processing in this analysis uses IBM SPSS Statistics 23. The analysis techniques are as follows (Sugiyono, 2015).

1. Reliability testing using the Cronbach Alpha coefficient. The variables are reliable if the Cronbach's Alpha coefficient is above 0.6 and if the coefficient is below 0.6 then the variable must be removed.

2. Validity testing, where the variables are valid if the significance value of the correlation is less than 5\%. The significance value shows the correlation between variables.

3. Analyzing the relationship between variables with the KMO test (KaiserMeyer-Olkin Measure of Sampling Adequacy) and Bartlet of Sphericity. if the KMO value is above 0.5 it means that there is a relationship between variables. If there are variables with a KMO value below 0.5 , the variable must be removed and re-analyzed until all variables have a KMO value above 0.5 .

4. MSA analysis (Measures of Sampling Adequacy) to determine the feasibility of variables. The feasible variable has an MSA value above 0.5. If the MSA value is less than 0.5 then the variable must be removed and re-analyzed until all variables have an MSA value above 0.5.

5. Component Matrix / Factor Loading analysis, in this analysis all variables must be on one factor (formed in one component). If it is not, the analysis is repeated by removing the variables that have the smallest MSA until one factor is formed (formed in one component).

\section{RESULTS AND DISCUSSION}

In principle, factor analysis is extracting factors from variables that have been determined through literature review to obtain fewer factors and have represented indicators in measuring the development of the Leuwiliang Agropolitan Area. Factor analysis is also one method for testing the reliability and validity of the instruments to be used. Reliability is the level of confidence in the questionnaire instrument. While validity means the ability of measurement in 
providing information that can be interpreted as a measurable achievement or characteristic (Sugiyono, 2015).

\subsection{Ecological Category}

Based on a literature review, there are 13 variables in the ecological category to be analyzed. The results of the ecological variable reliability test are shown in Table 1 . That table shows the Cronbach's Alpha reliability coefficient values is above 0.6, which means that all variables on ecological category are reliable (Nunnally (1970) in Yusrizal (2008))

Table 1. Results of Ecological Factors Reliability Test

\begin{tabular}{|ll|l|}
\hline NO & FACTORS & REABI \\
\hline 1 & Farmers' ability to produce certified seeds & \\
2 & The use of certified seeds & \\
3 & Farmers' ability to produce organik fertilizer & \\
4 & The use of organic fertilizers & \\
5 & Farmers' ability to produce natural pesticides & \\
6 & The use of organic pesticides & $\mathbf{0 , 6 8 5}$ \\
7 & Crop failure level & \\
8 & Farmers' ability to apply conservation & \\
9 & technology & \\
10 & Frequency of waste production & \\
11 & Environmental pollution & \\
12 & Level of Disaster Hazard & \\
13 & Land Management and Utilization & \\
\hline
\end{tabular}

Source: Author (2019)

There are 13 variables in the ecological category to be analyzed using the validity test. Validity test can be measured based on significance, KMO, and MSA value. The results of the validity test of ecological factors can be seen in Table 2. 
Table 2. Result of Ecological Factors Validity Test

\begin{tabular}{|c|c|c|c|c|c|c|}
\hline \multirow[t]{2}{*}{$\mathrm{NO}$} & \multirow[t]{2}{*}{ FACTORS } & \multicolumn{5}{|c|}{ RESULTS } \\
\hline & & $\begin{array}{l}\text { SIG } \\
\mathrm{N}\end{array}$ & $\begin{array}{l}\text { KM } \\
\mathrm{O}\end{array}$ & MSA & $\begin{array}{l}\text { COM } \\
\text { MAT }\end{array}$ & $\begin{array}{l}\text { NEN } \\
K\end{array}$ \\
\hline $\begin{array}{l}9 \\
10 \\
11 \\
12\end{array}$ & $\begin{array}{l}\text { Farmers' ability to produce certified } \\
\text { seeds } \\
\text { The use of certified seeds } \\
\text { Farmers' ability to produce organik } \\
\text { fertilizer } \\
\text { The use of organic fertilizers } \\
\text { Farmers' ability to produce natural } \\
\text { pesticides } \\
\text { The use of organic pesticides } \\
\text { Crop failure level } \\
\text { Farmers' ability to apply conservation } \\
\text { technology } \\
\text { Frequency of waste production } \\
\text { Environmental pollution } \\
\text { Level of Disaster Hazard } \\
\text { Land Use and Management } \\
\text { Agricultural land conversion }\end{array}$ & $\begin{array}{l}\mathbf{0 , 0 0} \\
\mathbf{0}\end{array}$ & $\begin{array}{l}0,80 \\
5\end{array}$ & $\begin{array}{l}0,812 \\
\text { remov } \\
\text { ed } \\
0,631 \\
0,838 \\
0,689 \\
0,693 \\
0,716 \\
0,763 \\
0,621 \\
\text { remov } \\
\text { ed } \\
\text { remov } \\
\text { ed } \\
0,588 \\
0,543\end{array}$ & $\begin{array}{l}0,722 \\
0,827 \\
0,754 \\
0,923 \\
0,481 \\
0,648 \\
0,851\end{array}$ & $\begin{array}{l}\text { formed in } \\
\text { one } \\
\text { componen } \\
\mathrm{t}\end{array}$ \\
\hline
\end{tabular}

Source: Author (2019)

Based on Table 2, 3 factors must be removed namely the use of certified seeds, environmental pollution, and level of disaster hazard. Those factors are removed due to low component matrix value and do not form in one component. Certified seeds, environmental pollution, and level of disaster hazard factors do not influence the development of the Leuwiliang agropolitan area because even though most of the farmers use uncertified seeds, they are still able to produce agriculture product even with low quality and productivity. Besides, the level of environmental pollution in Leuwiliang Agropolitan Area is low and its location is outside the disaster-prone zone. 
After reduction process of ecological factors, there are 10 ecological factors influencing to the development of the Leuwiliang Agropolitan Area such as (1) Farmers' ability to produce certified seeds; (2) Farmers' ability to produce organic fertilizer; (3) The use of organic fertilizers; (4) Farmers' ability to produce natural pesticides; (5) The use of organic pesticides; (6) Crop failure level; (7) Farmers' ability to apply conservation technology; (8) Frequency of waste production; (9) Land use and management; and (10) Agricultural land conversion. The use of organic pesticides has the largest matrix component value on the ecological category (0.959) compared to the other factors. Most farmers in the Leuwiliang Agropolitan Area tend to use chemical pesticides to prevent pests and diseases. The reason why farmer uses chemical pesticides is a habit and due to unavailability of natural pesticides on the market. The higher the dose of pesticides will impact on pest resistance. According to data from the Directorate General of Agricultural Facilities Infrastructure, the types of pesticides registered are increasing every year, as of 2016, there were 3,207 types of pesticides registered (Ditjen PSP, 2016).

\subsection{Economic Category}

Based on a literature review, there are 20 variables in the economic category to be analyzed. The results of the economic variable reliability test are shown in Table 2 . That table shows the Cronbach's Alpha reliability coefficient values is above 0.6, which means that all variables on economic category are reliable (Nunnally (1970) in Yusrizal (2008)).

Table 3. Results of Economic Factors Reliability Test

\begin{tabular}{|ll|l|}
\hline NO & FACTORS & REABIL \\
\hline 1 & Farmer's land area & \\
2 & Number of commodities cultivated by farmers & \\
3 & Quality of agricultural products & \\
4 & Land productivity & \\
5 & Farmer's place of origin & \\
6 & Number of farmer group members & \\
7 & Farmer's capital & \\
8 & Capital assistance for farmers & $\mathbf{0 , 6 1 9}$ \\
9 & Farmer dependence on subsidies & \\
10 & Agricultural commodity price fluctuations & \\
11 & Farmers marketing system & \\
\hline
\end{tabular}




\begin{tabular}{|ll|l|}
\hline 12 & Farmers market destinations & \\
13 & Number of farmer's income & \\
14 & Farmer's profit level & \\
15 & Farmer's income trends & \\
16 & Farmer's investment trends & \\
17 & Other sources of income & \\
18 & The number of taxes types paid by farmers & \\
19 & $\begin{array}{l}\text { Ratio of agricultural and non-agricultural products on the } \\
20\end{array}$ & $\begin{array}{l}\text { marketrasio ratio of place of origin on agricultural and non- } \\
\text { agricultural products }\end{array}$ \\
\hline
\end{tabular}

\section{Source: Author (2019)}

There are 20 variables in the economic category to be analyzed using the validity test. Validity test can be measured based on significance, KMO, and MSA value. The results of the validity test of economic factors can be seen in Table 4.

Table 4. Results of Economic Factors Validity Test

\begin{tabular}{|c|c|c|c|c|c|c|}
\hline \multirow[t]{2}{*}{$\mathrm{NO}$} & \multirow[t]{2}{*}{ FACTORS } & \multicolumn{5}{|c|}{ RESULTS } \\
\hline & & SIGN & $\begin{array}{l}\text { KM } \\
\text { O }\end{array}$ & MSA & $\begin{array}{l}\text { COMH } \\
\text { MATR }\end{array}$ & $\begin{array}{l}\text { NEN } \\
\mathrm{X}\end{array}$ \\
\hline $\begin{array}{l}1 \\
2 \\
3 \\
4 \\
5 \\
6 \\
7 \\
8 \\
9\end{array}$ & $\begin{array}{l}\text { Farmer's land area } \\
\text { Number of commodities cultivated by } \\
\text { farmers } \\
\text { Quality of agricultural products } \\
\text { Land productivity } \\
\text { Farmer's place of origin } \\
\text { Number of farmer group members } \\
\text { Farmer's capital } \\
\text { Capital assistance for farmers }\end{array}$ & 0,000 & 0,71 & $\begin{array}{l}0,559 \\
0,817 \\
\text { remove } \\
\text { d } \\
0,617 \\
\text { remove } \\
\text { d } \\
\text { remove } \\
\text { d } \\
0,806 \\
\text { remove }\end{array}$ & $\begin{array}{l}0,624 \\
0,756\end{array}$ & $\begin{array}{l}\text { forme } \\
d \text { in } \\
\text { one }\end{array}$ \\
\hline
\end{tabular}




\begin{tabular}{|c|c|c|c|c|c|}
\hline 12 & $\begin{array}{l}\text { Farmer dependence on subsidies } \\
\text { Agricultural commodity price } \\
\text { fluctuations } \\
\text { Farmers marketing system } \\
\text { Farmers market destinations } \\
\text { Number of farmer's income } \\
\text { Farmer's profit level } \\
\text { Farmer's income trends } \\
\text { Farmer's investment trends } \\
\text { Other sources of income } \\
\text { The number of taxes types paid by } \\
\text { farmers } \\
\text { Ratio of agricultural \& non-agricultural } \\
\text { products on the market } \\
\text { rasio of place of origin on agricultural } \\
\text { and non-agricultural products }\end{array}$ & 9 & $\begin{array}{l}\text { d } \\
0,856 \\
\text { remove } \\
\text { d } \\
\text { remove } \\
\text { d } \\
0,800 \\
0,637 \\
0,567 \\
0,785 \\
\text { remove } \\
\text { d } \\
0,826 \\
\text { remove } \\
\text { d } \\
\text { remove } \\
\text { d }\end{array}$ & $\begin{array}{l}0,717 \\
0,788 \\
0,797 \\
0,656\end{array}$ & $\begin{array}{l}\text { comp } \\
\text { onent }\end{array}$ \\
\hline
\end{tabular}

Source: Author (2019)

Based on Table 4, there are 10 variables that must be removed namely Quality of agricultural products, Farmer's place of origin, Number of farmer group members, Capital assistance for farmers, Agricultural commodity price fluctuation Farmers marketing system, Farmer's investment trends, The number of taxes types paid by farmers, Ratio of agricultural \& non-agricultural products on the market ratio dan ratio of place of origin on agricultural and nonagricultural products. Those factors are removed due to low component matrix value and do not form in one component so that they have no influence on the development of the Leuwiliang agropolitan area.

After reduction process of economic factors, there are 10 economic factors influencing to the development of the Leuwiliang Agropolitan Area such as (1) Farmer's land area; (2) Number of commodities cultivated by farmers; (3) Land productivity; (4) Farmer's capital; (5) Farmer dependence on subsidies; (6) Farmers market destinations; (7) Number of farmer's income; (8) 
Farmer's profit level;(9) Farmer's income trends; and (10) Other sources of income. Farmers profit level has the largest matrix component value on the economic category (0.797) compared to the other factors. Most farmers in the Leuwiliang Agropolitan Area always get profits from their agribusiness with low margins. The lack of profits obtained by farmers will affect on the low level of farmers' capital, so farmers can not develop their own business. research conducted by Handayani (2006) shows that farmers who have their own agricultural land will get higher profits.

\subsection{Social Culture Category}

Based on a literature review, there are 10 variables in the social culture category to be analyzed. The results of the social culture variable reliability test are shown in Table 5. That table shows the Cronbach's Alpha reliability coefficient values is above 0.6, which means that all variables on social culture category are reliable (Nunnally (1970) in Yusrizal (2008)).

Table 5. Results of Social - Culture Factors Reliability Test

\begin{tabular}{|lll|}
\hline NO & FACTORS & REABILITY \\
\hline 1 & Distance of farmers' house to land & \\
2 & Status of farmers' agricultural land \\
3 & Farmer age level \\
4 & Farmer education level \\
5 & Involvement of farmers family members in agriculture & $\mathbf{0 , 6 1 3}$ \\
6 & The use of farm workrs services \\
7 & Growth of farmers group members \\
8 & Number of poor population \\
9 & The existence of corporate social responsibility (CSR) \\
10 & Frequency of conflict in the community \\
\hline
\end{tabular}

Source: Author (2019)

There are 10 variables in the social culture category to be analyzed using the validity test. Validity test can be measured based on significance, KMO, and MSA value. The results of the validity test of social culture factors can be seen in Table 6 . 
Table 6. Results of Social - Culture Factors Validity Test

\begin{tabular}{|c|c|c|c|c|c|c|}
\hline \multirow[t]{2}{*}{ NO } & \multirow[t]{2}{*}{ FACTORS } & \multicolumn{5}{|c|}{ RESULTS } \\
\hline & & $\begin{array}{l}\text { SIG } \\
\mathbf{N}\end{array}$ & KMO & MSA & $\begin{array}{l}\text { COMI } \\
\text { MATI }\end{array}$ & $\begin{array}{l}\text { ONEN } \\
\text { IX }\end{array}$ \\
\hline $\begin{array}{l}1 \\
2 \\
3 \\
4 \\
5 \\
6 \\
7 \\
8 \\
9 \\
10\end{array}$ & $\begin{array}{l}\text { Distance of farmers' house to land } \\
\text { Status of farmers' agricultural land } \\
\text { Farmer age level } \\
\text { Farmer education level } \\
\text { Involvement of farmers family members } \\
\text { in agriculture } \\
\text { The use of farm workrs services } \\
\text { Growth of farmers group members } \\
\text { Number of poor population } \\
\text { The existence of corporate social } \\
\text { responsibility (CSR) } \\
\text { Frequency of conflict in the community }\end{array}$ & $\mathbf{0 , 0 0 0}$ & 0,695 & $\begin{array}{l}0,599 \\
0,739 \\
0,759 \\
0,701 \\
0,748 \\
0,653 \\
0,604 \\
0,749 \\
0,589 \\
\text { remove } \\
\text { d }\end{array}$ & $\begin{array}{l}0,806 \\
0,638 \\
0,654 \\
0,789 \\
0,814 \\
0,744 \\
0,802 \\
0,768 \\
0,671\end{array}$ & $\begin{array}{l}\text { formed in } \\
\text { one } \\
\text { compone } \\
\text { nt }\end{array}$ \\
\hline
\end{tabular}

Source: Author (2019)

Based on Table 6, there is only one factor that must be removed namely frequency of conflict in the community. That factors is removed due to low component matrix value and does not form in one component. Frequency of conflict in the community factors does not influence the development of the Leuwiliang agropolitan area because all this time, there has never been a conflict between the community and the government.

After reduction process of socio-cultural factors, there are 9 socio culture factors affecting to the development of the Leuwiliang agropolitan area such as (1) Distance of farmers' house to land; (2) Status of farmers' agricultural land; (3) Farmer age level; (4) Farmer education level; (5) Involvement of farmers family members in agriculture; (6) The use of farmworkers services; (7) Growth of farmers group members; (8) Number of poor population; and (9) The existence of corporate social responsibility (CSR). Involvement of farmers family members in agriculture has the largest matrix component value on social culture category (0.814) compared to the other factors. Support from farmers family members in the Leuwiliang Agropolitan Area is still low so that in managing an agribusiness, the farmer as the head of the family manages his own agribusiness without support from their family members. The regeneration conditions of farmers 
in the Leuwiliang Agropolitan area are very low, most young people have no desire to farm. They prefer to work in factories or trade outside the area to get a better livelihood. Nevertheless, in the Leuwiliang Agropolitan Area, there are five Farmer Women's Groups (KWT) who are farmers' wives. Most Farmer Women's Groups have agricultural processing business such as dodol, fruit syrup, and candied fruit. The existence of KWT can improve the household economy of farmers in the Agropolitan Region of Leuwiliang District.

\section{CONCLUSIONS}

\section{Findings}

Based on the result of the research, it can be concluded that the use of organic pesticides, farmers profit level and support from farmers family members in the Leuwiliang Agropolitan Area is the most influential factor from each category towards the development of Leuwiliang Agropolitan Area.

\section{Recommendations}

1. Strengthening the capacity of farmers in utilizing natural resources to produce components of production inputs (organic fertilizers and natural pesticides) that are more economical and environmentally friendly so that farmers can reduce production costs without damaging the environment.

2. Strengthening the role of women and young farmers in agribusiness in the agropolitan area. Women (wife) and young farmers (millennial) can provide a new model in the farm management system. Millennials / young farmers tend to have innovations in agriculture.

3. Increasing the efficiency of a sustainable agribusiness system through training for farmers so farmers can develop market-oriented farming so that they can maximize the profit.

\section{REFERENCES}

Bossel, H. (1999). Indicators for Sustainable Development: Theory, Method, Applications. International Institute for Sustainable Development (Vol. 68). Manitoba, Canada: International Institute for Sustainable Development.

BP4K of Bogor Regency. (2012). Agropolitan of Bogor Regency. Bogor: BP4K of Bogor Regency

Directorate General of agricultural facilities and infrastructure. (2016). Agricultural and forestry pesticide book registered 2016. Directorate General of agricultural facilities and infrastructure. Ministry of Agriculture.

Fatkhiati, S., Tjiptoherijanto, P., Rustiadi, E., \& Thayib, M. H. (2015). Sustainable agropolitan management models in the highland of tropical rainforest ecosystem: the case of Selupu Rejang agropolitan area, Indonesia. Procedia Environmental Sciences, 28, 613-622. https://doi.org/10.1016/j.proenv.2015.07.072

Friedmann, J., \& Douglass, M. (1975). Agropolitan Development: Towards a New Strategy for Regional Planning in Asia. Growth Pole Strategy and Regional Development Policy, 163192. https://doi.org/10.1016/B978-0-08-021984-4.50014-9 
Handayani, D.,M. (2006). Analysis of profitability and revenue of rice farming by land area and land ownership status (Case Study of Karacak Village, Leuwiliang Sub District, Bogor Regency). [Theses]. Economic of Agriculture and Resources, Faculty Of Agriculture. Bogor : Bogor Agricultural University.

Ismilaili, Purnaningsih, N., \& Asngari, P. S. (2015). Tingkat Adopsi Inovasi Pengelolaan Tanaman Terpadu (PTT) Padi Sawah di Kecamatan Leuwiliang, Kabupaten Bogor. Jurnal Penyuluhan, 11(1), 49-59.

Lo, F.-C., \& Salih, K. (1978). Growth Pole Strategy And Regional Development Policy: Asian Experience and Alternative Approaches. (F.-C. Lo \& K. Salih, Eds.), Pergamon Press (First Edit). Nagoya: Pergamon Press.

Lebacq, T., Baret, P. V., \& Stilmant, D. (2013). Sustainability indicators for livestock farming. A review. Agronomy for Sustainable Development, 33(2), 311-327. https://doi.org/10.1007/s13593-012-0121-x

Oktavia, S., \& Saharuddin. (2013). Relationship between the role of stakeholders with community participation in the agropolitan program Karacak Village, Leuwiliang District, Bogor Regency. Journal of Rural Sociology, 1 (3), 231246.https://doi.org/http://dx.doi.org/10.22500/sodality.v1i3.9407

Sugiyono. (2015). Research and Development Methods. Bandung: Alfabeta

Van Cauwenbergh, N., Biala, K., Bielders, C., Brouckaert, V., Franchois, L., Garcia Cidad, V., ... Peeters, A. (2007). SAFE-A hierarchical framework for assessing the sustainability of agricultural systems. Agriculture, Ecosystems and Environment, 120(2-4), 229-242. https://doi.org/10.1016/j.agee.2006.09.006

Yusrizal. (2008). Testing the construct validity by using factor analysis. Journal of Tabularasa PPS Unimed Vol. 5 No. 1, 73-92 